\title{
The Impact of Small Bowel Endoscopy in Patients with Hereditary Hemorrhagic Telangiectasia
}

\author{
Herediter Hemorajik Telenjiektazi Hastalarında Ince Barsak Endoskopisinin Önemi
}

\author{
(D) Stefania Chetcuti Zammit, (D) David S. Sanders, (D) Mark E. McAlindon, (D) Reena Sidhu \\ Sheffield Teaching Hospitals, Royal Hallamshire Hospital, Academic Department of Gastroenterology, Sheffield, England
}

To the Editor,

We have read with interest the article entitled "Thalidomide for the Management of Bleeding Episodes in Patients with Hereditary Hemorrhagic Telangiectasia: Effects on Epistaxis Severity Score and Quality of Life" [1].

This article highlights the use of thalidomide in the management of patients with hereditary hemorrhagic telangiectasia (HHT) who present with epistaxis. The prevalence of HHT is thought to be between 1.5 and 2 cases per 10,000 people [2]. HHT can be associated with other bleeding complications such as bleeding from the gastrointestinal tract and in particular the small bowel (SB). The existence of small bowel angioectasias (SBAs) has been reported to vary between $56 \%$ and $91 \%$ in the literature $[3,4,5,6]$. The study by Ingrosso et al. [6] also reported that patients with SBAs were considerably older.

We carried out a study at our tertiary center for the management of patients with HHT where 10 patients $(60 \%$ males) with genetically confirmed HHT were referred for the management of gastrointestinal-related complications. The impact of small bowel capsule endoscopy (SBCE) and double balloon enteroscopy (DBE) was evaluated. The mean age at first SB endoscopy was $62.6 \pm 14.4$ years (mean \pm standard deviation).

Patients had a total of 39 gastroscopies, 16 colonoscopies, and 6 push enteroscopies. Seven patients underwent SBCE: 6 (85.7\%) had proximal, 1 (11.1\%) had mid, and $3(33.3 \%)$ had distal SBAs. Two patients had a colon capsule that showed angioectasias.

Several DBEs were carried out for 6 patients (median 4; SD \pm 6 ) with a mean of $130.5 \pm 133.3$ days between DBEs. Fifty-seven SBAs were treated with argon plasma coagulation (APC) on average at each DBE. These procedures take an average of 75 minutes. Mean hemoglobin before and after the procedure was 9.8 and $10.2 \mathrm{~g} /$ $d \mathrm{~L}$, respectively $(p=0.1)$. Six patients were transfusion-dependent initially but 4 improved following intervention.

Need for transfusion resolved in 1 patient when started on lanreotide (a long-acting somatostatin analog), regular endoscopy, and APC, and in 2 patients upon starting DBEs and APC. One patient passed away from pneumonia. Another patient was switched unsuccessfully from octreotide to lanreotide. She stopped being transfusion-dependent with regular gastroscopies and APC. Another patient was unwilling to undergo further endoscopies due to multiple comorbidities. He improved on lanreotide. In 2 patients, anemia remains persistently problematic. One of them is also on dalteparin for superior mesenteric venous thrombosis. The other patient has recurrent epistaxis, which makes it harder for him to have further endoscopies.

SBCE is a useful screening tool in patients with HHT to assess SBAs. Although classed as invasive endoscopy, DBEs and APC can have a significant impact on mortality and quality of life in patients with HHT. Pharmacotherapy such as somatostatin analogs can additionally help to improve transfusion requirements. They have a good safety profile [7], unlike thalidomide, which can result in teratogenicity [8], peripheral neuropathy (50\%) [9], and thromboembolism [10].

Keywords: Hereditary hemorrhagic telangiectasia, Small bowel capsule endoscopy, Argon plasma coagulation

Anahtar Sözcükler: Herediter hemorajik telenjiektazi, İnce barsak kapsül endoskopisi, Argon plazma koagülasyonu

Informed Consent: Received.

Conflict of Interest: The authors of this paper have no conflicts of interest, including specific financial interests, relationships, and/or affiliations relevant to the subject matter or materials included.

\section{References}

1. Baysal M, Ümit EG, Kırkızlar HO, Özdöver AC, Demir AM. Thalidomide for the management of bleeding episodes in patients with hereditary hemorrhagic telangiectasia: effects on epistaxis severity score and quality of life. Turk J Hematol 2018 (in press).

2. Dakeishi M, Shioya $T$, Wada $Y$, Shindo T, Otaka K, Manabe M, Nozaki J, Inoue S, Koizumi A. Genetic epidemiology of hereditary hemorrhagic 
telangiectasia in a local community in the northern part of Japan. Hum Mutat 2002;19:140-148.

3. Canzonieri C, Centenara L, Ornati F, Pagella F, Matti E, Alvisi C, Danesino C, Perego $M$, Olivieri C. Endoscopic evaluation of gastrointestinal tract in patients with hereditary hemorrhagic telangiectasia and correlation with their genotypes. Genet Med 2014;16:3-10.

4. Grève E, Moussata D, Gaudin JL, Lapalus MG, Giraud S, Dupuis-Girod S, Calender A, Plauchu H, Saurin JC. High diagnostic and clinical impact of small-bowel capsule endoscopy in patients with hereditary hemorrhagic telangiectasia with overt digestive bleeding and/or severe anemia. Gastrointest Endosc 2010;71:760-767.

5. Chamberlain SM, Patel J, Carter Balart J, Gossage JR Jr, Sridhar S. Evaluation of patients with hereditary hemorrhagic telangiectasia with video capsule endoscopy: a single-center prospective study. Endoscopy 2007;39:516-520.

6. Ingrosso $M$, Sabbà $C$, Pisani $A$, Principi $M$, Gallitelli $M$, Cirulli $A$, Francavilla A. Evidence of small-bowel involvement in hereditary hemorrhagic telangiectasia: a capsule endoscopic study. Endoscopy 2004;36:1074-1079.
7. Holleran G, Hall B, Breslin N, McNamara D. Long-acting somatostatinanalogues provide significant beneficial effect in patients with refractory small bowel angioectasia: results from a proof of concept open label monocentre trial. United European Gastroenterol J 2016;4:70-76.

8. Sauer H, Gunther J, Hescheler J, Wartenberg M. Thalidomide inhibits angiogenesis in embryoid bodies by the generation of hydroxyl radicals. Am J Pathol 2000;156:151-158.

9. Izquierdo Navarro Mdel C, Hernando Verdugo M, Cardaba Garcia E, Sanchez Sanchez MT. Therapeutic failure with thalidomide in patients with recurrent intestinal bleeding due to angiodysplasias. Farm Hosp 2016;40:230-232.

10. Palumbo A, Rajkumar SV, Dimopoulos MA, Richardson PG, San Miguel J, Barlogie B, Harousseau J, Zonder JA, Cavo M, Zangari M, Attal M, Belch A, Knop S, Joshua D, Sezer O, Ludwig H, Vesole D, Bladé J, Kyle R, Westin J, Weber D, Bringhen S, Niesvizky R, Waage A, von Lilienfeld-Toal M, Lonial S, Morgan GJ, Orlowski RZ, Shimizu K, Anderson KC, Boccadoro M, Durie BG, Sonneveld P, Hussein MA; International Myeloma Working Group. Prevention of thalidomide- and lenalidomide-associated thrombosis in myeloma. Leukemia 2008;22:414-423.

\title{
Interleukin-2-330T/G and Interleukin-10-1082A/G Genetic Polymorphisms and B-Cell Non-Hodgkin Lymphoma
}

\author{
İnterlökin-2-330T/G ve İnterlökin-10-1082A/G Genetik Polimorfizmi ve B-Hücreli Non- \\ Hodgkin Lenfoma
}

\author{
(D) Beuy Joob1, (D) Viroj Wiwanitkit² \\ 1Sanitation 1 Medical Academic Center, Bangkok, Thailand \\ ${ }^{2}$ Honorary professor, Dr DY Patil University, Pune, India
}

To the Editor,

We read the publication "Association of Interleukin-2-330T/G and Interleukin-10-1082A/G Genetic Polymorphisms with B-Cell Non-Hodgkin Lymphoma (B-NHL) in a Cohort of Egyptians" with great interest [1]. Abdel Rahman et al. [1] concluded that "The present study highlights the possible involvement of the [interleukin (IL)] IL-2-330T/G genetic polymorphism in the susceptibility to [B-NHL] B-NHL in Egypt, especially indolent subtypes. Moreover, IL-10-1082A/G is not a molecular susceptibility marker for B-NHL in Egyptians" [1]. In fact, the role of polymorphism of IL is widely mentioned in relationship to NHL susceptibility [2]. We agree with the observation of Abdel Rahman et al. [1]. The differences of the effects of IL2-330T/G and IL-10-1082A/G can be explained by molecular quantum calculations of molecular weight changes. This is the same phenomenon as seen in other polymorphisms and it can affect the clinical appearance of many medical disorders, such as the effect of CTLA-4 A49G polymorphism on autoimmune blood disease [3]. For IL-2-330T/G and IL-10-1082A/G, the change of molecular weight is equal to -107.07 and +16 per molecule, respectively. This means that a molecule with IL$2-330 T / G$ requires more molecular mass and a molecule with IL-10-1082A/G requires less molecular mass to complete a biological process compared to a naïve molecule.

Keywords: Interleukin, Lymphoma, Polymorphism

Anahtar Sözcükler: İnterlökin, Lenfoma, Polimorfizm

Conflict of Interest: The authors of this paper have no conflicts of interest, including specific financial interests, relationships, 